\title{
Isolation and Characterization of West Nile Virus from the Blood of Viremic Patients During the 2000 Outbreak in Israel
}

\author{
Musa Hindiyeh,*† Lester M. Shulman,* E lla Mendelson,* \\ Lea Weiss,* Zehava Grossman,* and Hanna Bin* \\ *Israel Ministry of Health, Chaim Sheba Medical Center, Tel-Hashomer, Israel; \\ and $\dagger$ UNESCO Hebrew University of Jerusalem, Jerusalem, Israel
}

\begin{abstract}
We report the isolation of West Nile (WN) virus from four patient serum samples submitted for diagnosis during an outbreak of WN fever in Israel in 2000. Sequencing and phylogenetic analysis revealed two lineages, one closely related to a 1999 New York isolate and the other to a 1999 Russian isolate.
\end{abstract}

West Nile (WN) virus (1) outbreaks were recorded in Israel during the 1950s and 1970s (2-4); however, in the last decade, diagnosis ceased and no clinical cases were reported, although seroepidemiologic surveys indicated that the virus continued to circulate (5). Following reports of illness in birds in 1998, the Central Virology Laboratory (CVL) of the Public Health Services reestablished the capability to diagnose WN virus based on serologic assays, including virus neutralization, immunofluorescence, and enzyme-linked immunosorbent assays (ELISA) with immunoglobulin (Ig) G and IgM.

This led to the identification of acute human cases beginning in the fall of 1999 (6). High seroprevalence was found in the southern region of Israel (Eilot region) in the fall and winter of 1999-2000, with IgG levels ranging from $21 \%$ to $82 \%$ and IgM levels ranging from $0 \%$ to $73 \%$ in seven communities. Some IgM-positive cases were associated with clinical symptoms compatible with WN fever. Additional acute cases were diagnosed in the central region of Israel during the spring and summer of 2000 (H. Bin, unpub. data).

During the late summer and fall of 2000 , an outbreak occurred in the central and northern parts of Israel. Between August 1 and November 30, 439 patients with clinical symptoms were positive by ELISA-IgM testing; 29 of these patients died. The clinical details in records of the patients diagnosed at the CVL indicated that central nervous system (CNS) involvement was a major clinical manifestation in most hospitalized patients. Rates of illness and death increased with age: $69 \%$ of the patients were $>45$ years and $96 \%$ of those who died were $>65$ (Quarterly Report No. 3 of the Department of Epidemiology, Ministry of Health, Jerusalem). Epidemiologic and clinical aspects of the outbreak were also described by Weinberger et al. (7) and Chowers et al. (8), respectively. We describe the isolation and characterization of four viral strains from human serum obtained during this outbreak.

\section{The Study}

During the outbreak, patients' samples (serum, cerebrospinal fluid [CSF], or both) submitted to the CVL were

Address for correspondence: Ella Mendelson, Director, Central Virology Laboratory, Public Health Services, Ministry of Health, Chaim Sheba Medical Center, Tel-Hashomer, 52621, Israel; fax: 9723-530-2457; e-mail: ellamen@sheba.health.gov.il immediately divided into two aliquots. One aliquot was immediately used to test for IgM antibodies, and the other was stored at $-70^{\circ} \mathrm{C}$ until further processing. Virologic studies were performed on the frozen acute-phase samples from patients who seroconverted from IgM negative to IgM positive, as well as on CSF from fatal cases. Reverse transcription-polymerase chain reaction (RT-PCR) and virus isolation were attempted simultaneously on 32 patients' samples (17 serum and $15 \mathrm{CSF}$ ). RT-PCR and an indirect immunofluorescence assay (IFA) were used to confirm the presence of WN virus in cell culture. Direct sequencing of RTPCR amplified fragments was performed to characterize the genome of isolated viruses.

Patient samples were analyzed for WN virus by RT-PCR using primer sequences for the envelope gene, as described by Lanciotti et al. and Shi et al. $(9,10)$. Viral RNA was extracted by using the QIAamp Viral RNA Mini Kits (QIAgen Gmbh, Hilden, Germany), and the RT-PCR was performed with Ready to Go Beads (Amersham Pharmacia, Buckinghamshire, England) according to manufacturer's instructions. The primers Kun 108, Kun 848, Kun 998c, and Kun 1830c were used in RT-PCR for sequence analysis (11). Sequence analysis was performed on a 1648-bp fragment of the $\mathrm{WN}$ virus genome encoding $309 \mathrm{nt}$ upstream from the pre-membrane protein (preM), the entire preM and membrane protein $(\mathrm{M})$ genes, and $811 \mathrm{nt}$ of the 5 ' portion of the envelope glycoprotein (E) gene. Purification of the RT-PCR product and sequence and phylogenetic analyses were performed as described (12). Both strands of the amplified PCR products were sequenced. RTPCR conditions used were $42^{\circ} \mathrm{C}$ for $45 \mathrm{~min}, 95^{\circ} \mathrm{C}$ for $5 \mathrm{~min}$, $60^{\circ} \mathrm{C}$ for $2 \mathrm{~min}, 72^{\circ} \mathrm{C}$ for $2 \mathrm{~min}, 34$ cycles at $93^{\circ} \mathrm{C}$ for $45 \mathrm{sec}$, $55^{\circ} \mathrm{C}$ for $45 \mathrm{sec}$, and $72^{\circ} \mathrm{C}$ for $90 \mathrm{sec}$, followed by $72^{\circ} \mathrm{C}$ for $7 \mathrm{~min}$; samples were then left at $4^{\circ} \mathrm{C}$. PCR products were visualized by staining with ethidium bromide after electrophoresis on $2 \%$ agarose gels. With the RT-PCR assay, we can detect as low as $0.01 \mathrm{PFU}$ based on serially diluted titered WN virus isolated from a White-eyed Gull.

Virus isolation was performed on Vero cell monolayers (ATCC CCL-81) by using the tube method. Vero cell monolayers (80\%-90\% confluent) were washed twice with phosphate-buffered saline, then infected with 100 - to $200-\mu \mathrm{L}$ patient samples. Patient samples were allowed to adsorb for 1 hour at $37^{\circ} \mathrm{C}$ with gentle swirling every $15 \mathrm{~min}$. Eagle's 


\section{West Nile Virus}

minimal essential medium with $2 \%$ fetal calf serum, $100 \mathrm{U} /$ $\mathrm{mL}$ penicillin, $200 \mu \mathrm{g} / \mathrm{mL}$ streptomycin, and $12.5 \mathrm{U} / \mathrm{mL}$ nystatin was then added to the infected cells. Cells were monitored daily for 7 days for cytopathic effect (CPE). Cells showing CPE demonstrated rounding-up in the early stage of infection and many floating single cells later in the infection. Infected cells that showed CPE were evaluated by RT-PCR, and a sample $(100 \mu \mathrm{L})$ of the supernatant was passaged on another Vero cell monolayer to confirm WN virus. Infected cells that showed CPE were also evaluated by IFA using the monoclonal antibody JCU/KUN/2B2 (TropBio Pty Ltd., Townsville Queensland, Australia) (13). Cells from monolayers that did not show CPE were passaged onto fresh Vero cell monolayers and monitored for another 7 days. Cells that did not show CPE after 14 days were also tested with the IFA reagent. Only cell cultures that did not stain with IFA were reported negative.

Virus was isolated from serum from four nonfatal WN virus IgM-negative Israeli patients who seroconverted 1 to 2 weeks later. Patient 1 (WN-0043), a 51-year-old woman from the northcentral region, was hospitalized; CNS disease did not develop. Patient 2 (WN-0233), a 20-year-old man from the north, was hospitalized for fever of unknown origin and neutropenia; CNS disease did not develop. Patient 3 (WN0247), a 5-year-old boy residing in the central region, had meningoencephalitis and was hospitalized. Patient 4 (WN0304), a 55-year-old woman from the north, had high fever and myalgia and no CNS symptoms; she was not hospitalized.

Two viral isolates were detected from patients 3 and 4 on day 4 after inoculation on Vero cells; the other two isolates were detected from patients 1 and 2 on day 7 after inoculation. All four virus isolates were confirmed as WN virus by IFA. Only two original acute-phase serum samples (patients 3 and 4) were positive by RT-PCR. Negative RT-PCR results and lengthy time until appearance of CPE are apparently consistent with low viral load in patients' serum (Table).

Sequence analysis showed that isolates WN-0233 (GenBank Accession Number AF375043) and WN-0304 (GenBank Accession Number AF375045) had identical sequences over 1,648 nt and isolates WN-0043 (GenBank Accession Number AF375042) and WN-0247 (GenBank Accession Number AF375044) differed by only $1 \mathrm{nt}$. Such high homology is similar to results reported by Lanciotti et al., who also described identical WN virus sequences from brain samples from two patients (14). WN-0247 differed from WN0304 by $50(3 \%)$ of $1,648 \mathrm{nts}$ or $25(2.9 \%)$ of $855 \mathrm{nt}$ for the partial $\mathrm{E}$ gene sequence. Most differences in the $\mathrm{E}$ gene were

Table. Analysis of West Nile patients' isolates, Israel, 2000 outbreak

\begin{tabular}{|c|c|c|c|c|c|}
\hline Patients & $\begin{array}{l}\text { Virus } \\
\text { isolate }\end{array}$ & $\begin{array}{c}\text { RT-PCR } \\
\text { acute- } \\
\text { phase } \\
\text { serum }\end{array}$ & $\begin{array}{l}\text { Tissue } \\
\text { culture } \\
\text { acute- } \\
\text { phase } \\
\text { serum } \\
\text { (CPE+IFA) }\end{array}$ & $\begin{array}{c}\text { RT-PCR } \\
\text { infected } \\
\text { cell } \\
\text { culture }\end{array}$ & $\begin{array}{c}\text { RT-PCR } \\
\text { \& tissue } \\
\text { culture } \\
\text { convalescent- } \\
\text { phase } \\
\text { serum } \\
\end{array}$ \\
\hline 1 & WN-0043 & $(-)$ & $(+)$ & (+) & ND \\
\hline 2 & WN-0233 & $(-)$ & $(+)$ & $(+)$ & ND \\
\hline 3 & WN-0247 & $(+)$ & $(+)$ & $(+)$ & $(-)$ \\
\hline$\underline{4}$ & WN-0304 & $(+)$ & $(+)$ & $(+)$ & $(-)$ \\
\hline
\end{tabular}

+ , positive result; -, negative result; ND, not done; RT-PCR, reverse transcription-polymerase chain reaction; CPE, cytopathic effect; IFA, indirect immunofluorescence assay. in the third position of the codon ( 21 of 25 ); all of these were synonymous. All four differences in the first and second codon positions encoded different amino acids when isolate WN0247 was compared with isolate WN-0304.

A 255-nt fragment of the WN virus $\mathrm{E}$ gene has previously been used for phylogenetic studies (15-17). A search of the EMBL/GenBank database using the equivalent fragment of the Israeli outbreak isolates indicated that isolate WN-0043 and WN-0247 were identical to WN-flamingo-NY99, while isolates WN-0233 and WN-0304 were most closely related to the WN-Romania-97 isolate AF130362 (3-nt difference, 1.2\%) and less closely related to the WN-flamingo-Y99 (9-nt difference, $3.5 \%$ ).

A similar search, using a 1,648-nt fragment encoding the preM, M, and part of the 5' E gene, allowed the construction of a more detailed phylogenetic comparison (Figure). As with the 255-nt fragment, WN-0043 and WN-0247 were closest to WNflamingo-NY99 (AF196835, 99.7\% homology), while WN0233 and WN-0304 most closely resembled a 1997 isolate from Romania (AF130362, 98.4\% homology). Phylogenetic analysis showed that two lineages of WN virus circulate in Israel. The first is similar to the WN virus isolates from mosquito, horse, and flamingo during the 1999 NY outbreak. The other lineage is similar to the virus isolated from a mosquito pool during the 1997 Romanian outbreak and to the nucleotide sequences reported from the Russian outbreak in

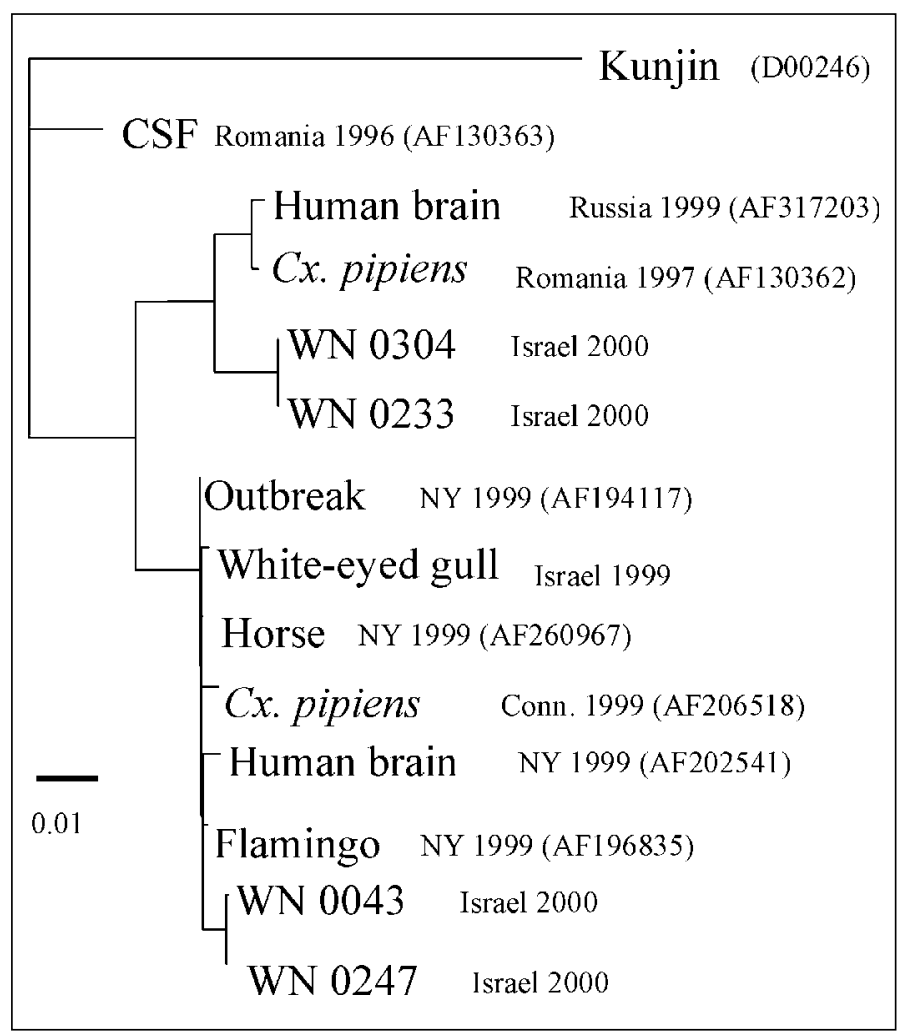

Figure. Phylogenetic comparison of human West Nile virus isolates from the Israel 2000 outbreak with sequences from the EMBL/ GenBank database. The PHYLIP DNA Maximum Likelihood program (bootstrap $=100$ ) was used to compare a 1,648-nt sequence encoding the PreM, M gene, and part of the E gene from the four human outbreak isolates with nine sequences from the EMBL/ GenBank database (accession numbers in parentheses) and one from a 1999 isolate from an Israeli White-eyed Gull. CSF = cerebrospinal fluid sample. 


\section{West Nile Virus}

1999. These two lineages isolated in Israel in the 2000 outbreak differ from the WN sequences obtained in 1996 from Romania (11).

\section{Conclusions}

Our sequence analysis shows that at least two lineages of WN virus infected the human population in Israel in 2000. Virus lineage and severity of symptoms were not clearly correlated, although more human isolates would be necessary to confirm this finding. More than one lineage can be found in areas where a virus is endemic and has been circulating for extended periods. More studies, using archived materials, are necessary to determine if there were more than two cocirculating lineages. Yet to be determined is whether changes in the virus genome resulted in a more virulent strain, which caused the high rates of illness and death during the 2000 Israeli outbreak.

\section{Acknowledgments}

We thank M. Malkinson, Y. Stram, C. Banet, and others from the Kimron Veterinary Institute, Ministry of Agriculture, Beit Dagan, Israel, for their support and help in establishing the diagnostic methods and providing virus isolates and useful information; R. Swanepoel, F. Burt, and B. Schoub for helping to establish our diagnostic abilities; L. Kramer and P-Y Shi for providing primer sequences for reverse transcription-polymerase chain reaction; all our staff members and in particular F. Mileguir, $R$. Pavel, P. Duvdevani, T. Frank, N. Stern, and D. Soffer for their tremendous work during the West Nile fever outbreak, which formed the basis for this research work; and A. Mates, A. Leventhal, and B. Lev for supporting our work.

This research work was funded by the Ministry of Health, Public Health Services, Israel. Dr. Hindiyeh's fellowship is supported by the Fritz Thyssen Foundation, Köln, Germany.

Dr. Hindiyeh, a clinical microbiologist, is a fellow at the UNESCO Hebrew University of Jerusalem, International School of Molecular Biology, Microbiology and Science for Peace. Dr. Hindiyeh is also receiving training in clinical virology and laboratory management at the Central Virology Laboratory, Public Health Services, Sheba Medical Center, TelHashomer. His scientific interest is in rapid detection of microbial pathogens.

\section{References}

1. Rice CM. Flaviviridae: the viruses and their replication. In: Fields BN, Knipe DM, Howley PM, Chanock RM, Melnick JL, Monath TP, et al., editors. Virology. Vol 1. New York: Lippincott-Raven; 1996. p.931-59.

2. Bernkopf $H$, Levine $\mathrm{S}$, Nerson R. Isolation of West Nile virus in Israel. J Infect Dis 1953;93:207-18.
3. Flatau E, Kohn D, Daher O, Varsano N. West Nile fever encephalitis. Isr J Med Sci 1981;17:1057-9.

4. Lustig S, Halevey M, Fuchs P, Pen-Nathan D, Lachmi BE, Kobiler D, et al. Can West Nile Virus outbreaks be controlled. IMAJ Math Appl Med Bio 2000;2:733-7.

5. Cohen D, Zaide Y, Karasenty E, Schwarz M, LeDuc JW, Slepon R, et al. Prevalence of antibodies to West Nile fever, sandfly fever Sicilian, and sandfly fever Naples viruses in healthy adults in Israel. Public Health Rev 1999;27:217-30.

6. Bin H, Pokamunsky S, Malkinson M, Banet C, Mendelson E. Emerging viral diseases, are we prepared for a new plague? [Abstract H1]. Annual meeting 2000 of the Israel Society for Microbiology, Haifa, Israel, 2000. ISM News 2000;30:24.

7. Weinberger M, Pitlik SD, Gandacu D, Lang R, Nassar F, Ben David D, et al. West Nile fever outbreak, Israel 2000: Epidemiologic aspects. Emerg Infect Dis 2001;7:686-9.

8. Chowers MY, Lang R, Nassar F, Ben David D, Giladi M, Rubinshtein E, et al. Clinical characteristics of the West Nile fever outbreak, Israel, 2000. Emerg Infect Dis 2001;7:675-8.

9. Lanciotti RS, Kerst AJ, Nasci RS, Godsey MS, Mitchell CJ, Savage HM, et al. Rapid detection of West Nile virus from human clinical specimens, field-collected mosquitoes, and avian samples by a TaqMan reverse transcriptase-PCR assay. J Clin Microbiol 2000;38:4066-71.

10. Shi P-Y, Kauffman EB, Ren P, Felton A, Tai JH, Dupuis AP II, et al. High-throughput detection of West Nile Virus RNA. J Clin Microbiol 2001;39:1264-71.

11. Savage HM, Ceianu C, Nicolescu G, Karabatsos N, Lanciotti R, Vladimirescue A, et al. Entomologic and avian investigations of an epidemic of West Nile fever in Romania, 1996, with serologic and molecular characterization of a virus from mosquitoes. Am J Trop Med Hyg 1999;61:600-11.

12. Shulman LM, Handsher R, Yang CF, Yang SUJU, Manor J, Vonsover A, et al. Resolution of the pathways of poliovirus Type 1 transmission during an outbreak. J Clin Microbiol 2000;38:945-52.

13. Hall RA, Burgess GW, Kay BH, Clancy P. Monoclonal antibodies to Kunjin and Kokobera viruses. Immunol Cell Biol 1991;69:47-9.

14. Lanciotti RS, Rohring JT, Deubel V, Smith J, Parker M, Steele K, Crise B, et al. Origin of the West Nile virus responsible for an outbreak of encephalitis in the Northeastern United States. Science 1999;286:2333-7.

15. Berthet FX, Zeller HG, Drouet MT, Rauzier J, Digoutte JP, Deubel V. Extensive nucleotide changes and deletions within the envelope glycoprotein gene of Euro-African West Nile viruses. J Gen Virol 1997;78:2293-7.

16. Coia GP, Speight G, Byrne ME, Westway EG. Nucleotide and complete amino acid sequences of Kunjin virus: definitive gene order and characteristics of the virus specific proteins. J Gen Virol 1988;69:1-21.

17. Gould EA, Zanotto P, Holmes EC. The genetic evolution of flaviviruses. In: Saluzzo JF, Dodet B, editors. Factors in the emergence of arbovirus diseases. Paris: Elsevier Press; 1997. p. 51-63. 